\title{
Pyogenic versus amoebic liver abscesses. A comparative clinical study in a series of 58 patients
}

\author{
A. Cosme ${ }^{1}$, E. Ojeda ${ }^{2}$, I. Zamarreño ${ }^{2}$, L. Bujanda ${ }^{1}$, G. Garmendia ${ }^{3}$, M. J. Echeverría ${ }^{4}$ and J. Benavente ${ }^{2}$ \\ ${ }^{I}$ Gastroenterology Department. Donostia Hospital. CIBEREHD. University of the Basque Country. San Sebastián, \\ Guipúzcoa. Spain. Departments of ${ }^{2}$ Internal Medicine, ${ }^{3}$ Radiology, and ${ }^{4}$ Microbiology. Donostia Hospital. San Sebastián, \\ Guipúzcoa. Spain
}

\begin{abstract}
Objective: to compare the clinical and epidemiological characteristics of patients with pyogenic liver abscess (PLA) and with amebic liver abscess (AHA) in order to determine the potential factors that may help improve diagnosis and treatment for this disease.

Material and method: a retrospective study of clinical histories of 45 patients with PLA and 13 with ALA, diagnosed between 1985 and 2005 in Donostia Hospital in San Sebastián.

Results: among the 45 patients with PLA (30 men and 15 women, with a mean age of 61 years and 11 months), more than a half were cholangitic (13 cases) or were of unknown origin (15 cases). In 10 patients, diabetes was considered to be a predisposing condition. Increased ESR (> 30), leukocytosis (> 12,000), fever and abdominal pain were observed in 95.5\%, 86.7\%, $82.8 \%$ and $68.9 \%$, respectively. Twenty-five patients had single abscesses. Abscess and blood cultures were positive in $77.1 \%$ and $50 \%$ of cases, respectively (44.4\% with polymicrobial infection). $E$. coli and $S$. milleri were the most commonly found germs. A percutaneous drainage was performed on 22 patients. Mean hospital stay was 27 days, and overall mortality, including that related to concomitant conditions, was 7 of 45 cases.

Of the 13 cases of ALA ( 7 men and 6 women, with mean age of 42,9 years), 2 were locally acquired. Increased AF and GGTP $(>2 \mathrm{~N})$, fever, leukocytosis and ESR (> 30) were observed in 92.3, 77, 70 and $61.5 \%$ of cases, respectively. There were single abscesses in 10 patients and all except one were located in the right lobe. The serological test for $E$. histolytica (IFF $\geq 1 / 256$ ) was positive in $100 \%$ of cases. A percutaneous drainage was carried out on 6 patients. Mean hospital stay was 18 days and two patients died.
\end{abstract}

Conclusions: In our series, the clinical parameters suggesting pyogenic origin were: age 50 or older, male gender, diabetes,

Received: 01-04-09.

Accepted: 28-10-09.

Correspondence: Ángel Cosme Jiménez. Servicio de Aparato Digestivo. Hospital Donostia. Paseo Dr. Beguiristain, s/n. 20014 San Sebastián. email: acosme@chdo.osakidetza.net
Cosme A, Ojeda E, Zamarreño I, Bujanda L, Garmendia G, Echeverria MJ, Benavente J. Pyogenic versus amoebic liver abscesses. A comparative clinical study in a series of 58 patients. Rev Esp Enferm Dig 2010; 102: 90-99.

moderately elevated bilirubin and transaminases. In amoebic cases the associated features were being aged 45 or younger, diarrhoea, and presence of a single abscess in the right lobe. Parasitism by $E$. histolytica must be considered in the differential diagnosis of liver abscesses, even with no epidemiological clinical history of travel and/or immigration.

Key words: Liver abscess. Pyogenic. Amoebic. Comparison.

\section{INTRODUCTION}

The incidence of pyogenic liver abscess (PLA) ranges from 1.1 to 2.3 cases per 100,000 population every year $(1,2)$. PLA occurs mainly in immunosuppressed and diabetic patients, and in individuals suffering from malignant neoplasia. Its prevalence has increased in recent years due to liver transplantation. Clinical characteristics depend on the pathogenic mechanism involved. Mortality rates have been reported as 6-32\% in various hospital series $(2,3)$.

Parasitism by Entamoeba histolytica in developed countries occurs in specific population subgroups: immigrants and travellers coming from endemic regions, psychiatric hospital patients, individuals with occasional contact with people coming from areas with amoebiasis, and those who have ingested contaminated food. The prevalence of infection by E. histolytica in Spain is low: $0.7 \%$ in the Barcelona hospital population (1978) (4), a percentage of $1.79 \%$ in a population in the northern area of Huelva province (1998) (5), and between 2.2 to $21 \%$ in adult immigrants (2002) (6). Mortality rates range 
from less than $1 \%$ in patients with abscesses without complications to $34 \%$ in complicated cases (7). The approximate incidence of amoebic liver abscess (ALA) in Guipuzcoa is of 0.1 cases for every 100,000 people every year.

In this study, liver abscess cases are reviewed retrospectively to establish the clinical differences between the pyogenic and amoebic aetiologies, thereby facilitating early treatment in these patients. Some of these cases have been the subject of prior reviews and communications $(8,9)$.

\section{PATIENTS AND METHOD}

The clinical histories of patients diagnosed with PLA and ALA between 1985 and 2005 in Donostia Hospital, San Sebastián, were reviewed retrospectively.

Pyogenic liver abscess was defined as the observation of one or more ultrasound and CT images with positive cultures, or by positivity in two or more blood cultures of germs consistent with the diagnosis. Hepatic lesions diagnosed by imaging techniques, but without positive cultures of the pus, were included after ruling out other diseases according to the clinical history. An amoebic aetiology was demonstrated by serology (antibody titre against $E$. histolytica by IIF $\geq 1 / 256$ ), faeces and/or abscess culture, and by location in the liver by imaging techniques.

The following variables were taken into account: age, sex, clinical features, blood and other diagnostic tests, type of abscess and location within the liver, treatment, evolution, and average hospital stay in both series. In addition, predisposing diseases and the origin of abscesses for pyogenic abscesses (45 cases), and associated diseases, epidemiological history of travelling to areas with a high prevalence of amoebiasis, the origin of patients, and the time between having been to endemic areas and the occurrence of symptoms in amoebic cases (13 cases) were analysed.

\section{Statistical analysis}

In order to evaluate the differences between demographic data for PLA and ALA, the chi square test and/or Fisher's test were used for categorical variables, and Student's t-test and the non-parametric Mann-Whitney U test for quantitative variables. Differences between groups were considered to be significant when $\mathrm{p}$ value was less than 0.05 .

\section{RESULTS}

During the two decades studied, 45 patients were diagnosed with PLA caused by bacteria, and there were 13 cases of ALA. The clinical features and laboratory data of the two series are shown in table I. Predisposing conditions for pyogenic abscesses were: diabetes mellitus (10 cases); tumours (4, out of which 2 had liver metastasis); chronic pancreatitis (4); hydatid cysts; (3) infection by HIV (1); and liver cirrhosis (1). The origin of the abscess was biliary in 13 cases, phlebitis of the portal vein in 5, spread of infection from previous liver lesions in 5 , haematogenic in 4 , by contiguity in 3 , and 15 of unknown origin.

The clinical history of patients with amoebic abscesses included: malaria, chronic liver disease due to hepatitis B and $\mathrm{C}$ viruses (1 case), and chronic obstructive pulmonary disease COPD (1 case). Eleven out of thirteen lived in Guipuzcoa, one lived in Uruguay (was on holiday in Guipuzcoa), and another came from Japan (but had been living in Guipuzcoa for the previous 6 months). Eleven had travelled to areas where the disease is endemic -India (4), Mexico (3), Costa Rica, Uganda, Guinea and Morocco (1)-. In $82 \%$ of cases symptoms appeared within the first 5 months after the visit. Two individuals did not have any history of exposure to endemic areas. One of them may have been infected by their partner who suffered from amoebic colitis, and the other one had a risk factor due to his/her profession (drain cleaner). Concomitant amoebic colitis was present in 5 patients.

Table I. Clinical characteristics and blood test results in patients with liver abscesses

\begin{tabular}{|c|c|c|c|c|c|}
\hline \multirow[t]{2}{*}{ Parameters analysed } & \multicolumn{2}{|c|}{ Pyogenic abscess (45 cases) } & \multicolumn{2}{|c|}{ Amoebic abscess (13 cases) } & \multirow[b]{2}{*}{$p$ (value) } \\
\hline & No/total & Percentage & No/total & Percentage & \\
\hline Age, year (range) & $\begin{array}{c}61 \text { years and } \\
11 \text { months }(29-84)\end{array}$ & & $\begin{array}{l}42 \text { years and } \\
9 \text { months }(24-77)\end{array}$ & & 0.04 \\
\hline $\operatorname{Sex}(M / F)$ & $30 / 15$ & - & $7 / 6$ & - & NS \\
\hline Fever & $37 / 45$ & 82.2 & $10 / 13$ & 46.1 & NS \\
\hline Right upper quadrant pain/abdominal pain & $31 / 45$ & 68.9 & $6 / 13$ & 30.7 & NS \\
\hline Respiratory symptoms & $4 / 45$ & 8.9 & $4 / 13$ & 23 & NS \\
\hline Constitutional syndrome & $22 / 45$ & 48.9 & $3 / 13$ & 15.3 & NS \\
\hline Icterus ( $\mathrm{Bi}>2 \mathrm{mg}$ ) & $24 / 45$ & 53.3 & $2 / 13$ & 61.5 & 0.02 \\
\hline $\operatorname{ESR}(>30 \mathrm{~mm})$ & $43 / 45$ & 95.5 & $8 / 13$ & 70 & 0.004 \\
\hline Leukocytes (> 12,000 $\mu / \mathrm{l})$ & $39 / 45$ & 86.7 & $9 / 13$ & 92.3 & NS \\
\hline ALP and/or GGT (> 2N) & $23 / 42$ & 54.8 & $11 / 13$ & 53.8 & NS \\
\hline AST and/or ALT (> 2N) & $9 / 41$ & 21.9 & $7 / 13$ & & 0.04 \\
\hline
\end{tabular}

M: male. F: female. NS: not significant. A: abscess. 
Microbiological diagnoses and findings from imaging techniques for the 58 patients studied are shown in tables II and III. Abdominal echography was performed on 50 patients, leading to a diagnosis in $38(76 \%)$, while a CT scan was carried out on 55, and a diagnosis was reached in $96 \%$ of these cases (Fig. 1). The micro-organisms isolated from the pyogenic abscesses were: aerobic gram negative rods (23 cases), anaerobic bacteria (15), aerobic gram positive cocci (14), aerobic gram positive rods (1) and Brucella (1). A total of 44.4\% (12 out of 27) of abscesses with a bacteriological diagnosis were polymicrobial. E. coli and S. milleri (21 cases) were the most commonly found germs. Amoebic abscesses were larger than $10 \mathrm{~cm}$ in diameter in 5 cases (4 single and 1 multiple), and larger than $5 \mathrm{~cm}$ in a further 7 cases (5 single and 2 multiple).

Table II. Bacteriology in patients with liver abscess

\begin{tabular}{lcccc}
\hline Microbiological diagnosis & \multicolumn{2}{c}{$\begin{array}{c}\text { Pyogenic } \\
\text { abscess (45) }\end{array}$} & \multicolumn{2}{c}{$\begin{array}{c}\text { Amoebic } \\
\text { abscess (13) }\end{array}$} \\
\hline & No/total & Percentage & $N^{\circ}$ /total & Percentage \\
\hline Culture of the abscess & $27 / 35$ & 77.1 & $4 * / 11$ & 36.3 \\
Blood culture & $15 / 30$ & 50 & - & - \\
Serology (IFI $\geq 1 / 256)$ & - & - & $11 / 11$ & 100 \\
Parasites in faeces & - & - & $2 * / 11$ & 18.1 \\
\hline
\end{tabular}

A: abscess. IFI: indirect immunofluorescence. ${ }^{*}$ Trophozoites of $E$. histolytica in pus or cysts in faeces.

Table III. Type and intrahepatic location of abscesses (58 patients)

\begin{tabular}{lccc}
\hline Distribution & Pyogenic (45) & Amoebic (13) & $p$ (value) \\
\hline Type & & & \\
Single & 25 & 10 & NS \\
Multiple & 20 & $3^{*}$ & \\
\hline Location & & & NS \\
$\quad$ Right lobe & 33 & 11 & \\
$\quad$ Left lobe & 5 & 1 & \\
Both lobes & 7 & 1 & \\
\hline
\end{tabular}

* Two were double and one multiple. NS: not significant.

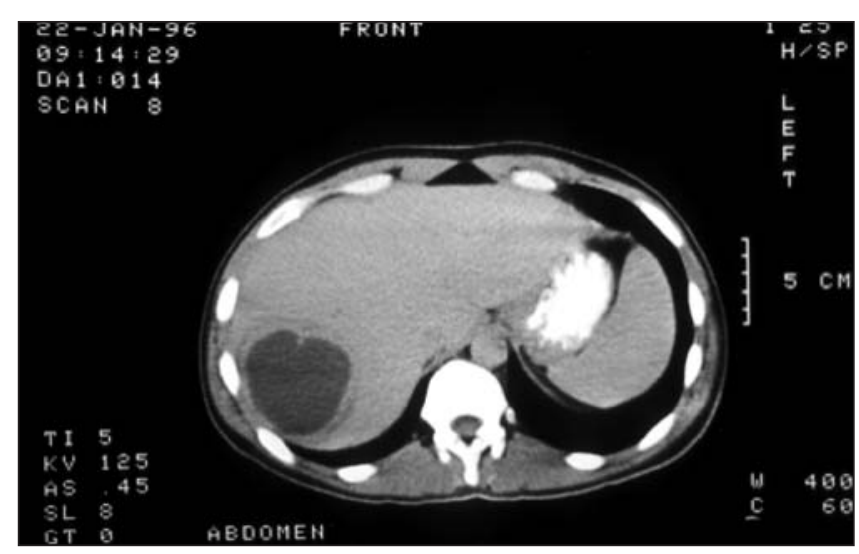

Fig.1. Amoebic abscess. Absceso amebiano.
The treatment of patients with PHA consisted of antibiotherapy, drainage and surgery. The most commonly used antibiotic combination were third generation cephalosporins with metronidazole, alone or with aminoglycosides (17 cases), imipenem or piperacillin-tazobactam (16), and aminoglycosides with metronidazole (5). Antibiotic therapy without drainage was carried out in 10 patients (one recurred and needed surgery due to biliary stenosis). CT-guided percutaneous drainage in association with adequate antibiotic coverage was used in 22 patients (Table IV). This procedure was successful in 18 (full recovery $81.8 \%$ ). In 13 patients, where the drainage was not successful, surgery was undertaken. Overall mortality was related to the diseases that needed surgical treatment (acute cholecystitis, obstructive icterus, infected hydatid cyst in the liver, peritonitis, postoperative biliary stenosis, and carcinoma of the gallbladder). The average hospital stay of those patients who were treated with percutaneous drainage was shorter than that of those treated with surgery ( 21 versus 40 days).

Table IV. Treatment and evolution of the patients with liver abscesses (58 cases)

\begin{tabular}{lccc}
\hline Parameters & $\begin{array}{c}\text { Pyogenic } \\
\text { abscess }\end{array}$ & $\begin{array}{c}\text { Amoebic } \\
\text { abscess }\end{array}$ & $p$ (value) \\
\hline Patients $(n)$ & 45 & 13 & \\
$\begin{array}{l}\text { Overall average stay (days) } \\
\text { Patients treated with percutaneous }\end{array}$ & 27 & 18 & NS \\
$\quad$ drainage ( $n$ ) & 22 & 6 & NS \\
$\begin{array}{l}\text { Average stay of patients treated with } \\
\quad \text { percutaneous drainage (days) }\end{array}$ & 21 & 14 & NS \\
Overall mortality & $7^{*}$ & 2 & NS
\end{tabular}

A: abscess. NS: not significant. N: number. ${ }^{*}$ Including mortality related to concomitant diseases.

Patients suffering with ALA were treated with metronidazole and paramomycin as a first choice. CT-guided percutaneous drainage was carried out in 6 cases ( 5 of them with abscess sizes exceeding $10 \mathrm{~cm}$ ), and surgery in 4 cases. Mortality rates and mean hospital stay are shown in table IV. Two people died; one due to peritonitis secondary to multiple perforations in the colon due to amoebic ulcerative colitis (Fig. 2) in association with septic shock, and the other one due to large multiple abscesses with sepsis and respiratory distress.

\section{DISCUSSION}

Amoebiasis is a protozoan disease that affects $10 \%$ of the world population with a high prevalence in Mexico and South Africa (among the black population), some areas in the Middle East, South and Southeast Asia, and parts of Western Africa and South America. ALA occurs in between 3 and $9 \%$ of the people infected with the parasite. In Spain, during the last decade, there has been an 


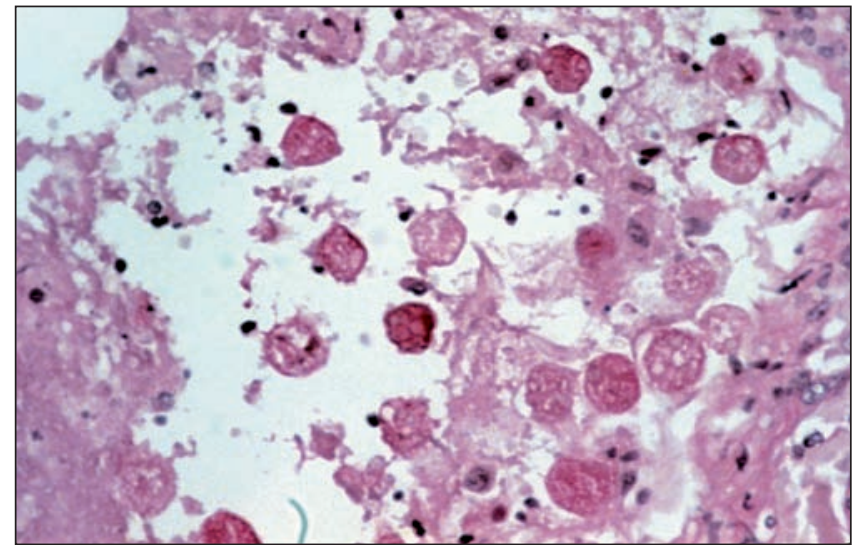

Fig. 2. Trophozoites and amoebic cysts in the colon.

Trofozoitos y quistes amebianos en colon.

increase in the number of autochthonous cases. Some series of patients suffering from ALA have indicated a predilection for middle-aged men, and that it is less common at extreme ages (10-13).

PHA has a variable occurrence in the population according to concomitant diseases. The risk of developing a pyogenic abscess in diabetic people and in those suffering from malignant tumours is tenfold higher than that of the general population; in patients who have undergone liver transplantation it is 445 times higher (2). PHA often occurs in individuals over 50 years old with a slight predominance in men $(14,15)$. Abscesses secondary to ascending cholangitis and of unknown origin are the most common.

ALA is caused by the colonization of the liver by trophozoites of pathogenic strains of E. histolytica through portal circulation. It causes foci of necrosis in the liver parenchyma, most of the time leading into a single cavity. The most common clinical signs and symptoms are abdominal pain (70-100 of the cases) in association with fever (70-100\%) and diarrhoea, with or without blood (30-50\% of the cases). Sometimes, the abscess only causes fever.

The classical symptomatology of PLA (fever, shivering, and pain in the lower right abdomen with or without hepatomegaly, of subacute presentation), occurs in a small percentage of patients. In recent Spanish series $(9,16-20)$, up to $60 \%$ of patients lack symptoms suggestive of processes in the lower right abdomen. Icterus is often associated with biliary pathology. Table $\mathrm{V}$ shows the differential characteristics of PLA and ALA from other studies in Central and South American and Asian countries $(14,15,21-24)$.

Blood tests for both types of abscesses are similar: increased ESR, leukocytosis with left shift, and slight changes in liver function tests. In cases secondary to biliary tract infection, bilirubin levels are often increased. In blood tests in amoebic infections there is often a moderate increase of alkaline phosphatase; icterus is rare and, when present, moderate.

Abdominal contrast CT is the technique of choice for the diagnosis of liver abscesses. In our series, it helped in the diagnosis of lesions in $96 \%$ of patients, similar to what is reported in the literature $(3,9,12,23,25,26)$. Its sensitivity is almost $100 \%$ higher than echography, which remains the first examination to be carried out because of its low cost and ready availability. However, both CT scans and echography may lead to false negatives in abscesses smaller than $1 \mathrm{~cm}$ in diameter, in those located near the diaphragmatic dome, and in those in early stages of development.

The microbiological diagnosis of pyogenic abscesses is based on the identification of the germ by culture, with

Table V. Comparative clinical characteristics in several series of patients with pyogenic versus amoebic liver abscesses

\begin{tabular}{|c|c|c|c|c|c|c|c|}
\hline Author & Ogden et al. (21) & May et al. (22) & $\begin{array}{l}\text { Barbour and } \\
\text { Juniper (14) }\end{array}$ & Conter et al. (15) & Barnes et al. (23) & Lodhi et al. (24) & Cosme \\
\hline $\begin{array}{l}\text { Year of publication } \\
\text { Period of study } \\
\text { Country } \\
N^{0} \text { of patients } \\
\text { PLAVALA } \\
\text { Predominance in males } \\
\text { Age }>50 \text { years } \\
\text { Diabetes mellitus } \\
\text { Thoracic pain/cough } \\
\text { Crepitants/rhonchi } \\
\text { Abdominal pain } \\
\text { Diarrhoea } \\
\text { Bilirubin } \\
\text { Increased ALP } \\
\text { Single abscess } \\
\text { Abscess in RL }\end{array}$ & $\begin{array}{c}1961 \\
\text { USA (New-Orleans) } \\
136 \\
84 / 51 \\
\text { Amoebic } \\
- \\
- \\
- \\
- \\
- \\
- \\
- \\
- \\
- \\
\text { Amoebic }\end{array}$ & $\begin{array}{c}1967 \\
\text { 1943-1966 } \\
\text { USA (Dallas) } \\
39 \\
24 / 15 \\
\text { Amoebic } \\
\text { Pyogenic } \\
- \\
\text { Amoebic } \\
\text { Amoebic } \\
\text { NS } \\
\text { Amoebic } \\
\text { Pyogenic } \\
\text { NS } \\
- \\
\text { Amoebic }\end{array}$ & $\begin{array}{c}1972 \\
1940-1969 \\
\text { USA (Arkansas) } \\
66 \\
33 / 33 \\
\text { NS } \\
\text { Pyogenic } \\
- \\
- \\
\text { NS } \\
\text { Amoebic } \\
\text { Amoebic } \\
- \\
\text { Amoebic } \\
- \\
\text { NS }\end{array}$ & $\begin{array}{c}1986 \\
1968-1983 \\
\text { USA (California) } \\
82 \\
42 / 40 \\
\text { NS } \\
\text { Pyogenic } \\
- \\
\text { NS } \\
\text { NS } \\
\text { Amoebic } \\
\text { Amoebic } \\
\text { Pyogenic } \\
\text { Pyogenic } \\
\text { NS } \\
\text { NS }\end{array}$ & $\begin{array}{c}1987 \\
1979-1985 \\
\text { USA (California) } \\
144 \\
48 / 96 \\
\text { Amoebic } \\
\text { Pyogenic } \\
\text { Pyogenic } \\
\text { Pyogenic } \\
- \\
\text { Amoebic } \\
\text { Amoebic } \\
\text { Pyogenic } \\
\text { NS } \\
\text { NS } \\
\text { NS }\end{array}$ & $\begin{array}{c}2004 \\
\text { 1988-1998 } \\
\text { Pakistan } \\
577 \\
106 / 471 \\
\text { Amoebic } \\
\text { Pyogenic } \\
\text { Pyogenic } \\
\text { NS } \\
\text { Pyogenic } \\
\text { NS } \\
\text { NS } \\
\text { NS } \\
\text { NS } \\
\text { Amoebic } \\
\text { Amoebic }\end{array}$ & $\begin{array}{c}2009 \\
1985-2005 \\
\text { Basque Country (Gipuzkoa) } \\
58 \\
45 / 13 \\
\text { NS } \\
\text { Pyogenic } \\
\text { Pyogenic } \\
\text { NS } \\
\text { NS } \\
\text { NS } \\
\text { Amoebic } \\
\text { Pyogenic } \\
\text { NS } \\
\text { NS } \\
\text { NS }\end{array}$ \\
\hline
\end{tabular}

For all the parameters, the difference between PHA and ALA was significant ( $<$ 0.5). Insufficient data for comparison. NS: not significant. PHA: pyogenic liver abscess. ALA: amoebic hepatic abscess. ALP:alkaline phosphatase. RL: right lobe. 
samples obtained from the liver by FNA $-70-95 \%$ of cases $(9,15-20,23)-$, or by blood culture $-40-60 \%$ of cases (9,15-20,23)-. In amoebic abscesses several methods were used: detection of specific antigens (adhesine GalGalNac) and serum antibodies against E. histolytica, fecal smear test, FNA of abscesses, and molecular biology techniques. Of these, the serological test (indirect hemaglutination) is the most sensitive (positive in 90$100 \%$ of the cases), while faecal smear test and microbiological culture are least affordable. PCR is considered the gold standard for immigrants coming from endemic areas and frequent travellers who carry antibodies against $E$. histolytica for several years after being infected. Currently, a very specific technique which can be used for the diagnosis of ALA as long as the subject has not been treated with amoebacides is the presence of adhesin Gal-GalNac in the serum (27).

The treatment of choice for PLA (echo or CT-guided percutaneous drainage in association with antibiotics) cures between 72 and $90 \%$ of patients, with complications ranging from 4 to $18 \%$ (28-30). The absolute contraindications for guided drainage are when there is an indication for surgery because of an associated disease or significant coagulopathy. Relative contraindications are ascites, very viscous purulent material, multiple small abscesses, and the risk of damaging vital structures, especially those in the left lobe. Surgery is performed when percutaneous treatment fails, or there are absolute or relative contraindications for guided drainage, associated diseases secondary to surgical treatment, or abscesses with rupture or haemorrhage. Antibiotic treatment without drainage is controversial. It should be applied only in patients with small abscesses and always considering each individual case $(9,28)$. In our series, such diverse treatments are explained by the fact that patients were seen at different points over a long period (20 years).

The treatment for ALA consists of the intraluminal and systemic administration of amoebacides as soon as possible. Guided percutaneous drainage is performed in case of large abscesses $(>8 \mathrm{~cm})(31)$, those located in the left lobe, and when there is no response to medical treatment or liver failure is present. There is no current evidence whether guided percutaneous drainage provides extra benefits compared to treatment with metronidazole alone in uncomplicated ALA cases (32). Surgical treatment is performed if percutaneous drainage fails or complications arise. Mortality rates are lower than $1 \%$ in uncomplicated cases (without superinfection or rupture to the peritoneum, pleura or pericardium).

The limitations of this study are its retrospective, observational nature, and that it includes a relatively small number of cases compared to other Central and South American Asian studies. However, it represents one of the few series in our country (12) in which the clinical pictures of these two types of liver abscesses are compared.
As a conclusion, in our series PLA occurred in people aged 50 or over, often with diabetes, and generally associated with bilirubin levels over $2 \mathrm{mg} / \mathrm{dL}$. On the other hand, subjects with ALA had an epidemiological history of travel or immigration. Diarrhoea was one of the initial symptoms of the disease, and they had a single abscess predominantly in the right lobe.

\section{REFERENCES}

1. Hansen PS, Schonheyder HC. Pyogenic hepatic abscess: a ten year population-based retrospective study. APMIS 1998; 106: 396-402.

2. Kaplan GG, Gregson DB, Laupland KB. Population-based study of the epidemiology of and the risk factors for pyogenic liver abscess. Clin Gastroenterol Hepatol 2004; 2: 1032-8.

3. Cosme Jiménez A, Bujanda Fernández de Piérola L, Ojeda Pérez E. Abscesos hepáticos piógenos. El especialista opina. Disponible en: http://www.nacom.es/Med 1/3/doc/expertodocumentos/2001.

4. Portús M, Prats G. Contribución al conocimiento de las protozoosis intestinales en la población hospitalaria barcelonesa. Med Clin (Bar) 1981; 76: 203-5.

5. Perea R, Bassas E, Lepe JA, Lombardo M, Garcés M. Prevalencia de anticuerpos frente a Entamoeba histolytica en la zona norte de la provincia de Huelva. Med Clin (Bar) 1998; 110: 275.

6. Pérez Arellano JL, Muro Álvarez A, Hernández Cabrera M, Martín Sánchez AM. Amebosis. Medicine (Madrid) 2002; 8: 3731-41.

7. Ortiz FM, Devesa F, Ferrando J, Ferrando I, Borghol A, Gutiérrez J. Absceso hepático amebiano: ¿tratamiento farmacológico o punciónaspiración? Gastroenterol Hepatol 2007; 30: 399-401.

8. Pérez Trallero E, Cilla Eguiluz G, Urbieta Egaña M, Muñoz Baroja I. Infecciones autóctonas por Entamoeba histolytica. Med Clin (Bar) 1985; 85: 254 .

9. Barrio J, Cosme A, Ojeda E, Garmendia G, Castiella A, Bujanda L, et al. Abscesos hepáticos piógenos de origen bacteriano. Estudio de una serie de 45 casos. Rev Esp Enferm Dig 2000; 92: 232-5.

10. Djossou F, Malvy D, Tamboura M, Beylot J, Lamouliatte H, LongyBoursier M, et al. Amoebic liver abscess. Study of 20 cases with literature review. Rev Med Inter 2003; 24: 97-106.

11. García-Forcada A, Sans M, Gascon J, Valls ME, Bru C, Corachan M. Absceso hepático amebiano: revisión de 13 casos. Med Clin (Bar) 1995; 105: 537-40.

12. Blanco Quintana F, Novellas Arribas B, Sánchez Molini P, Sanz Sanz J. Descriptive study of 39 cases of hepatic abscess of pyogenic and amebic origin. An Med Interna (Madrid) 1995; 12: 477-84.

13. Nari GA, Ceballos Espinosa R, Carrera Ladrón de Guevara S, Preciado Vargas J, Cruz Valenciano JL, Briones Rivas JL et al. Abscesos amebianos de hígado. Tres años de experiencia. Rev Esp Enferm Dig 2008; 100: 268-72.

14. Barbour GL, Juniper K. A clinical comparison of amebic and pyogenic abscess of the liver in sixty-six patients. Am J Med 1972; 53 : 323-34.

15. Conter RL, Pitt HA, Tompkins RK, Longmire WP. Differentiation of pyogenic from amebic hepatic abscess. Surg Gynecol Obstr 1986; 162: 114-20.

16. Comas P, Vargas V, Almirante B, González A, García D, Esteban R, et al. Absceso piógeno hepático. Revisión de 33 casos. Rev Clin Esp 1989; 185: 225-30.

17. Corbella X, Vadillo M, Torras J, Pujol M, Rafecas A, Gudiol F. Presentación, diagnóstico y tratamiento del absceso hepático piógeno: análisis de una serie de 63 casos. Enferm Infecc Microbiol Clin 1995; 13: 80-4.

18. Ramos A, Gazapo T, Murillas J, Martín H, Mandaza P, Cuervas V. Absceso hepático piógeno. Estudio descriptivo de 35 casos. Gastroenterol Hepatol 1996; 19: 292-6.

19. Asensi V, Rodríguez A, Carton JA, Maradona JA, Álvarez E, Llera JM, et al. Abscesos hepáticos piógenos. Revisión de 59 casos y experiencia con imipenem. Rev Clin Esp 1997; 197: 494-9.

20. Jiménez E, Tiberio G, Sánchez J, Jiménez FJ, Jiménez G. Abscesos hepáticos piógenos: experiencia de 16 años en su diagnóstico y 
tratamiento. Enferm Infecc Microbiol Clin 1998; 16: 307-11.

21. Ogden WW, Hunter PR, Rives JD. Liver abscess. Postgrad Med 1961; 30: 11-9.

22. May RP, Lehmann JD, Sanford JP. Difficulties in differentiating amebic from pyogenic liver abscess. Arch Intern Med 1967; 119: 6974.

23. Barnes PF, De Cock KM, Reynolds TN, Ralls PW. A comparison of amebic and pyogenic abscess of the liver. Medicine (Baltimore) 1987; 66: 472-83.

24. Lodhi S, Sarwari AR, Muzammil M, Salam A, Smego RA. Features distinguishing amoebic from pyogenic liver abscess: a review of 577 adult cases. Trop Med Int Health 2004; 9: 718-23.

25. Greenstein AJ, Barth J, Dicker A, Bottone EJ, Aufses AH. Amebic liver abscess: a study of 11 cases compared with a series of 38 patients with pyogenic liver abscess. Am J Gastroenterol 1985; 80: 472-8.

26. Ahsan T, Jehangir MU, Mahmood T, Ahmed N, Saleem M, Shahid $\mathrm{M}$, et al. Amoebic versus pyogenic liver abscess. J Pak Med Assoc 2002; 52: 497-501.

27. Haque R, Mollah NU, Ali IK, Alam K, Eubanks A, Lyerly D, et al.
Diagnosis of amebic liver abscess and intestinal infection with the TechLab Entamoeba histolytica II antigen detection and antibody tests. J Clin Microbiol 2000; 38: 3235-9.

28. Seeto RK, Rockey DC. Pyogenic liver abscess. Changes in etiology, management and outcome. Medicine (Baltimore) 1996; 75: 99-113.

29. Bru C, Ayuso MC, Bianchi L, De la Torre P, Texeidor N. Abscesos hepáticos: drenaje percutáneo bajo control ecográfico. Gastroenterol Hepatol 1986; 9: 15-20.

30. Eroles G, Mecina AB, Fernández C, Mancebo AB, Riva L. Abscesos hepáticos: revisión retrospectiva de 68 casos. An Med Interna (Madrid) 2008; 5: 335-41.

31. Graillet R, Sánchez-Aguilar M, Morán-Mendoza AO, HernándezSierra JF, Gordillo-Moscoso A, Tapia-Pérez JH. Análisis de factores asociados al fracaso del tratamiento médico del absceso hepático amebiano. Cir Esp 2008; 84: 83-6.

32. Chavez-Tapia NC, Hernández-Calleros J, Tellez-Avila FI, Torre A, Uribe M. Image-guided percutaneous procedure plus metronidazole versus metronidazole alone for uncomplicated amoebic liver abscess (Review). Cochrane Database Syst Rev 2009; 21(1): CD004886.

\title{
Absceso hepático piógeno versus amebiano. Estudio clínico comparativo de una serie de 58 casos
}

\author{
A. Cosme ${ }^{1}$, E. Ojeda ${ }^{2}$, I. Zamarreño ${ }^{2}$, L. Bujanda ${ }^{1}$, G. Garmendia ${ }^{3}$, M. J. Echeverría ${ }^{4}$ y J. Benavente ${ }^{2}$ \\ ${ }^{I}$ Servicio de Aparato Digestivo. Hospital Donostia. CIBEREHD. Universidad del País Vasco. San Sebastián. Guipúzcoa. \\ Servicios de ${ }^{2}$ Medicina Interna, ${ }^{3}$ Radiología y ${ }^{4}$ Microbiología. Hospital Donostia. San Sebastián. Guipúzcoa.
}

\section{RESUMEN}

Objetivo: comparar las características clínicas y epidemiológicas de los pacientes con absceso hepático piógeno (AHP) y con absceso hepático amebiano (AHA) para establecer posibles factores que ayuden a mejorar el diagnóstico y tratamiento de la enfermedad.

Material y método: se realiza un estudio retrospectivo de las historias clínicas de 45 pacientes con AHP y de 13 con AHA, diagnosticados entre 1985 y 2005 en el Hospital Donostia de San Sebastián.

Resultados: de los 45 casos de AHP (30 hombres y 15 mujeres con una edad media de 61 años y 11 meses), más de la mitad fueron de origen colangítico (13 casos) o criptogenético (15 casos). La diabetes como enfermedad predisponente se objetivó en 10. La elevación de la VSG (>30), leucocitosis ( $>12.000)$, fiebre y dolor abdominal se observaron en el 95,5, 86,7, 82,8 y 68,9\% de los casos respectivamente. Los abscesos fueron solitarios en 25 casos. Los cultivos del absceso y los hemocultivos fueron positivos en el 77,1 y $50 \%$, respectivamente $(44,4 \%$ de los casos eran polimicrobianos). E. coli y $S$. milleri fueron los gérmenes más habituales. Se hizo drenaje percutáneo en 22 pacientes. La mortali- dad global, incluida la relacionada con la patología subyacente, fue de 7 casos y la estancia media hospitalaria de 27 días.

De los 13 casos de AHA ( 7 hombres y 6 mujeres con una edad media de 42 años y 9 meses), 2 fueron autóctonos. La elevación de la FA y GGTP $(>2 \mathrm{~N})$, fiebre, leucocitosis y VSG $(>30)$ se observaron en el 92,3, 77, 70 y 61,5\% de los casos respectivamente. Los abscesos fueron únicos en 10 casos y excepto uno, 12 se localizaron en el lóbulo derecho. La serología a E. histolytica (IFI $\geq 1 / 256$ ) fue positiva en el $100 \%$ de los casos. Se hizo drenaje percutáneo en 6 pacientes. La mortalidad fue de 2 casos y la estancia media hospitalaria de 18 días.

Conclusiones: en nuestra serie, las características clínicas que sugieren un origen piógeno son: la edad superior a 50 años, el sexo masculino, la diabetes y la bilirrubina y transaminasas moderadamente elevadas. En el amebiano, la edad menor de 45 años, la diarrea y la localización solitaria del absceso en el lóbulo derecho. La parasitación por E. histolytica se debe considerar en el diagnóstico diferencial de los abscesos hepáticos, incluso sin el antecedente epidemiológico de viajes o de inmigración.

Palabras clave: Absceso hepático. Piógeno. Amebiano. Comparación. 


\section{INTRODUCCIÓN}

La incidencia del absceso hepático piógeno (AHP) varía de 1,1 a 2,3 casos por 100.000 habitantes/año $(1,2)$. Los AHP suceden sobre todo en pacientes inmunodeprimidos, diabéticos o con neoplasias malignas. Su frecuencia ha aumentado en los últimos años debido a los trasplantes hepáticos. Las características clínicas dependen del mecanismo patogénico. La mortalidad es del 6-32\% en diferentes series de hospitales $(2,3)$.

La parasitación por Entamoeba histolytica en los países industrializados ocurre en subgrupos determinados de población: inmigrantes y viajeros procedentes de áreas endémicas, enfermos de hospitales psiquiátricos, sujetos que tienen contactos puntuales con individuos provenientes de zonas con amebiasis y consumidores de alimentos contaminados. La prevalencia de la infestación por $E$. histolytica en España es baja: 0,7\% en la población hospitalaria de Barcelona (1978) (4), 1,79\% en una población de la zona norte de la provincia de Huelva (1998) (5) y del 2,2 al $21 \%$ en los inmigrantes adultos (2002) (6). La mortalidad es menor del $1 \%$ en los pacientes con abscesos sin complicaciones y llega hasta el $34 \%$ en los complicados (7). La frecuencia aproximada del absceso hepático amebiano (AHA) en Guipúzcoa es de 0,1 caso por 100.000 habitantes/año.

Se revisan de forma restropectiva los abscesos hepáticos para establecer las diferencias clínicas entre los de etiología piógena y amebiana, y así facilitar el tratamiento precoz de estos pacientes. Algunos de los casos han sido objeto de estudio en revisiones y comunicaciones previas $(8,9)$.

\section{PACIENTES Y MÉTODO}

Se revisan retrospectivamente las historias clínicas de los pacientes diagnosticados de AHP y de AHA durante el periodo comprendido entre 1985 y 2005 en el Hospital Donostia de San Sebastián.
Se definió el absceso piógeno como la observación de una o varias imágenes de colecciones hepáticas por ecografía o TAC con cultivos positivos de las mismas o por la positividad de dos o más hemocultivos de gérmenes compatibles con el diagnóstico. Las lesiones hepáticas diagnosticadas por técnicas de imagen pero sin cultivos positivos del pus se incluyeron tras descartar otras enfermedades por la historia clínica. La etiología amebiana se demostró mediante serología (títulos de anticuerpos frente a $E$. histolytica por IFI $\geq 1 / 256$ ), cultivo de heces y/o del absceso, y la localización hepática por técnicas de imagen.

Se estudian la edad, sexo, características clínicas, datos analíticos, pruebas diagnósticas, tipo de absceso y localización en el hígado, tratamiento, evolución y estancia media hospitalaria de los pacientes de ambas series. En la de abscesos piógenos (45 casos) se analizan también las enfermedades predisponentes y el origen de los abscesos, y en la de los amebianos (13 casos), las enfermedades asociadas, el antecedente epidemiológico de viaje a áreas de alta prevalencia de amebiasis, la procedencia de los pacientes y el tiempo de aparición de los síntomas desde el viaje a zonas endémicas.

\section{Análisis estadístico}

Para evaluar las diferencias entre los datos demográficos de los AHP y de los AHA se utilizó el test de Chi cuadrado $y / o$ test de Fisher para las variables cualitativas y el test " $t$ " de Student y el no paramétrico U de Mann-Whitney para las cualitativas. Se consideraron diferencias significativas entre grupos cuando el valor de la $\mathrm{p}$ fue menor de 0,05 .

\section{RESULTADOS}

Durante estos 20 años se diagnosticaron 45 pacientes con AHP de origen bacteriano y 13 con AHA. Las características clínicas y datos analíticos de las 2 series se recogen en la tabla I. Las enfermedades predisponentes a la

Tabla I. Características clínicas y datos analíticos de los pacientes con absceso hepático

\begin{tabular}{|c|c|c|c|c|c|}
\hline \multirow[t]{2}{*}{ Parámetros analizados } & \multicolumn{2}{|c|}{ A. piógeno (45 casos) } & \multicolumn{2}{|c|}{ A. amebiano (13 casos) } & \multirow[b]{2}{*}{$p$ (valor) } \\
\hline & Nototal & Porcentaje & No/total & Porcentaje & \\
\hline Edad, años (límite) & $\begin{array}{c}61 \text { años y } \\
11 \text { meses (29-84) }\end{array}$ & & $\begin{array}{c}42 \text { años y } \\
9 \text { meses }(24-77)\end{array}$ & & 0,04 \\
\hline $\operatorname{Sexo}(H / M)$ & $30 / 15$ & - & $7 / 6$ & - & NS \\
\hline Fiebre & $37 / 45$ & 82,2 & $10 / 13$ & 46,1 & NS \\
\hline Dolor HD/abdominal & $31 / 45$ & 68,9 & $6 / 13$ & 30,7 & NS \\
\hline Síntomas respiratorios & $4 / 45$ & 8,9 & $4 / 13$ & 23 & NS \\
\hline Síndrome constitucional & $22 / 45$ & 48,9 & $3 / 13$ & 15,3 & NS \\
\hline Ictericia $(\mathrm{Bi}>2 \mathrm{mg})$ & $24 / 45$ & 53,3 & $2 / 13$ & 61,5 & 0,02 \\
\hline $\operatorname{VSG}(>30 \mathrm{~mm})$ & $43 / 45$ & 95,5 & $8 / 13$ & 70 & 0,004 \\
\hline Leucocitosis (> 12,000 $\mu / \mathrm{l})$ & $39 / 45$ & 86,7 & $9 / 13$ & 92,3 & NS \\
\hline FA y/o GGT $(>2 \mathrm{~N})$ & $23 / 42$ & 54,8 & $11 / 13$ & 53,8 & NS \\
\hline AST y/o ALT (> 2 N) & $9 / 41$ & 21,9 & $7 / 13$ & & 0,04 \\
\hline
\end{tabular}

H: hombre; M: mujer; NS: no significativa; A: absceso. 
aparición de los abscesos piógenos fueron: diabetes mellitus (10 casos), tumores (4, dos con metástasis hepáticas), pancreatitis crónica (4), quiste hidatídico hepático (3), infección por VIH (1) y cirrosis hepática (1). El origen del absceso fue colangítico en 13 de los 45 casos, pileflebítico en 5, por sobreinfección de lesiones hepáticas previas en 5 , hematógeno en 4 , por contigüidad en 3 y criptogenético en 15.

Los antecedentes de los sujetos con absceso amebiano fueron: paludismo y portador de hepatopatía crónica por virus B y C (1 caso) y EPOC (1 caso). De los 13 , once residían en Guipúzcoa, uno procedía de Uruguay (veraneaba en Donosti) y otro de Japón (residía en Guipúzcoa desde 6 meses antes). Once viajaron a zonas endémicas de la enfermedad -India (4), México (3), Costa Rica, Uganda, Guinea y Marruecos (1)-. En el $82 \%$ de los casos los síntomas aparecieron durante los 4 primeros meses después del viaje. En 2 sujetos no existió el antecedente de exposición en áreas endémicas. Uno fue contagiado probablemente por su pareja que tuvo colitis amebiana y el segundo tuvo como factor de riesgo su profesión (limpieza de alcantarillas). La colitis amebiana simultánea al absceso se evidenció en 5 pacientes.

El diagnóstico microbiológico y los hallazgos de las técnicas de imagen de los 58 pacientes estudiados se reseñan en las tablas II y III. La ecografía abdominal se hizo en 50 pacientes, siendo diagnóstica en 38 (76\%) y la TAC en 55, con diagnóstico de absceso en el $96 \%$ (Fig. 1). Los microorganismos aislados en los abscesos piógenos fueron: bacilos gramnegativos aerobios (23 casos), bacterias anaerobias (15), cocos grampositivos aerobios (14), bacilos grampositivos aerobios (1) y Brucella (1).

Tabla II. Bacteriología de los pacientes con absceso hepático

\begin{tabular}{lcccc}
\hline Diagnóstico microbiológico & \multicolumn{2}{c}{ A. piógeno (45) } & \multicolumn{2}{c}{ A. amebiano (13) } \\
\hline & No/total & Porcentaje & $N^{\circ} /$ total & Porcentaje \\
\hline Cultivo del absceso & $27 / 35$ & 77,1 & $4 * / 11$ & 36,3 \\
Hemocultivo & $15 / 30$ & 50 & - & - \\
Serología (IF $\geq 1 / 256)$ & - & - & $11 / 11$ & 100 \\
Parásito en heces & - & - & $2 * / 11$ & 18,1 \\
\hline
\end{tabular}

A: absceso; IFI: inmunofluorescencia indirecta; ${ }^{\star}$ Trofozoitos de $E$. histolytica en pus o quistes en heces.

Tabla III. Tipo y localización intrahepática del absceso (58 pacientes)

\begin{tabular}{lccc}
\hline Distribución & Piógeno (45) & Amebiano (13) & $p$ (valor) \\
\hline Tipo & & & \\
Único & 25 & 10 & NS \\
Múltiple & 20 & $3^{*}$ & \\
\hline Localización & & & NS \\
$\quad$ Lóbulo derecho & 33 & 11 & \\
Lóbulo izquierdo & 5 & 1 & \\
$\quad$ Ambos lóbulos & 7 & 1 & \\
\hline
\end{tabular}

*Dos fueron dobles y uno múltiple. NS: no significativa.
El 44,4\% (12 de 27) de los abscesos con diagnóstico bacteriológico fueron polimicrobianos. E. coli y $S$. milleri (21 casos) fueron los gérmenes más habitualmente aislados. Los abscesos amebianos fueron mayores de $10 \mathrm{~cm}$ en 5 casos (4 únicos y 1 múltiple) y de $5 \mathrm{~cm}$, en 7 (5 únicos y 2 dobles).

El tratamiento de los pacientes con AHP consistió en antibióticos, drenaje o cirugía. Las pautas más utilizadas fueron la asociación de cefalosporinas de tercera generación con metronidazol solo o con aminoglucósidos (17 casos), imipenem o piperacilina-tazobactam (16), y aminoglucósidos con metronidazol (5). La terapia antibiótica sin drenaje se llevó a cabo en 10 pacientes (uno recidivó y precisó cirugía por estenosis de la vía biliar). Se practicó drenaje percutáneo guiado por TAC, asociado a una cobertura antibiótica adecuada en 22 pacientes (Tabla IV). Este procedimiento fue definitivo en 18 (curación $81,8 \%$ ). En otros 13 enfermos y en los que fracasó el drenaje percutáneo se hizo cirugía. La mortalidad global estuvo en relación con las enfermedades de base que precisaron tratamiento quirúrgico (colecistitis aguda, ictericia obstructiva, hidatidosis hepática infectada, peritonitis, estenosis post-quirúrgica de la vía biliar y carcinoma vesicular). La estancia media hospitalaria de los tratados con drenaje percutáneo fue menor que la de los tratados con cirugía (21 versus 40 días).

En los pacientes con AHA se instauró tratamiento con metronidazol más paramomicina como primera elección. El drenaje percutáneo guiado por TAC se realizó en 6 casos ( 5 eran abscesos mayores de $10 \mathrm{~cm}$ ) y cirugía, en 4. La mortalidad y la estancia media hospitalaria se resumen en la tabla IV. Los dos fallecidos fueron: uno, por peritonitis secundaria a perforaciones múltiples del colon por colitis ulcerosa amebiana (Fig. 2) junto a shock séptico y el segundo, por grandes abscesos múltiples con sepsis y distrés respiratorio.

Tabla IV. Tratamiento y evolución de los pacientes con absceso hepático (58 casos)

\begin{tabular}{lccc}
\hline Parámetros analizados & A. piógeno & A. amebiano & $p$ (valor) \\
\hline Pacientes $(n)$ & 45 & 13 & \\
$\begin{array}{l}\text { Estancia media global (días) } \\
\text { Pacientes tratados con drenaje }\end{array}$ & 27 & 18 & NS \\
$\begin{array}{l}\text { percutáneo ( } n \text { ) } \\
\text { Estancia media de los pacientes tratados }\end{array}$ & 22 & 6 & NS \\
$\quad$ con drenaje percutáneo (días) & 21 & 14 & NS \\
Mortalidad global & $7^{*}$ & 2 & NS \\
\hline
\end{tabular}

A: absceso; NS: no significativa; N: número; *Se incluye la relacionada con las enfermedades concomitantes.

\section{DISCUSIÓN}

La amebiasis es una enfermedad protozoaria que afecta al $10 \%$ de la población mundial con una prevalencia elevada en México y Sudáfrica (raza negra), áreas del Oriente Medio, Sur y Sudeste Asiático, y zonas oeste de 
África y Sudamérica. El AHA aparece en el curso evolutivo del 3 al 9\% de los sujetos con esta parasitosis. En España, durante la última década, ha aumentado el número de casos autóctonos. En algunas series de AHA se comprueba una predilección por los varones de mediana edad y es menos habitual en los de edades extremas (10-13).

El AHP tiene una incidencia variable en la población según las diferentes enfermedades concomitantes. El riesgo de desarrollar un absceso piógeno en los diabéticos y en los individuos con tumores malignos es 10 veces superior al de la población general y en los pacientes con trasplante de hígado, 445 veces (2). El AHP ocurre por lo general en personas mayores de 50 años con un predominio escaso por el sexo masculino $(14,15)$. Los abscesos secundarios a una colangitis ascendente y los criptogenéticos son los más comunes.

El AHA se debe a la colonización del hígado por trofozoitos de cepas patógenas de E. histolytica a través de la circulación portal. En el parénquima hepático produce focos de necrosis que la mayoría de las veces confluyen hacia una cavidad única. La clínica más frecuente es la sensación de dolor abdominal (70-100\% de los casos) que se acompaña de fiebre (70-100\% de los casos) y diarrea con o sin sangre (30-50\% de los casos). En ocasiones, el absceso cursa sólo con fiebre.

La sintomatología clásica de los AHP consistente en fiebre, escalofríos y dolor en hipocondrio derecho con o sin hepatomegalia, de aparición subaguda, está presente en un porcentaje bajo de pacientes. En las series actuales españolas $(9,16-20)$ hasta un $60 \%$ de los enfermos carecen de síntomas sugestivos de proceso localizado en hipocondrio derecho. La ictericia suele asociarse a la presencia de patología biliar acompañante. En la tabla V se muestran las características diferenciales de los AHP en relación a los AHA de otros países americanos y asiáticos (14,15,21-24).

Los datos de laboratorio en ambos tipos de absceso son semejantes: elevación de la VSG, leucocitosis con desviación izquierda y alteración discreta de las pruebas hepáticas. En los casos secundarios a infección de la vía biliar, la bilirrubina está normalmente alta. En los amebianos suele haber un aumento moderado de la fosfatasa alcalina y la ictericia es rara pero cuando existe es moderada.

La TAC abdominal con contraste es la técnica de elección para el diagnóstico de los abscesos hepáticos. En nuestra serie contribuyó al diagnóstico de las lesiones en el $96 \%$ de los casos, porcentaje similar al de la literatura $(3,9,12,23,25,26)$. Su sensibilidad alcanza casi el $100 \%$, mayor que la de la ecografía, que es la primera exploración a realizar debido a su bajo coste y fácil disponibilidad. Tanto la TAC como la ecografía pueden dar falsos negativos en los abscesos menores de un centímetro de diámetro, en las lesiones proximales a la cúpula diafragmática y en aquellos que están en periodo temprano de su formación.

El diagnóstico microbiológico de los abscesos piógenos se basa en la identificación del germen mediante cultivo obtenido de la lesión hepática por PAAF (70-95\% de los casos) $(9,15-20,23)$ o por hemocultivo $(40-60 \%$ de los casos) $(9,15-20,23)$. En los amebianos se utilizan varios métodos: la detección de antígenos específicos (adhesina Gal-GalNac) y de anticuerpos séricos frente a E. histolytica, el estudio coproparasitario, la PAAF del absceso y las técnicas de biología molecular. La prueba serológica (hemaglutinación indirecta) es la más sensible (positiva en el 90-100\% de los casos) mientras que el estudio coproparasitario y el cultivo del absceso son menos renta-

Tabla V. Riesgos clínicos comparativos de varias series de pacientes con absceso hepático piógeno versus absceso hepático amebiano

\begin{tabular}{|c|c|c|c|c|c|c|c|}
\hline Autor & Ogden et al. (21) & May et al. (22) & $\begin{array}{c}\text { Barbour y } \\
\text { Juniper (14) }\end{array}$ & Conter et al. (15) & Barnes et al. (23) & Lodhi et al. (24) & Cosme \\
\hline $\begin{array}{l}\text { Año de publicación } \\
\text { Periodo de estudio } \\
\text { País } \\
\text { No de pacientes } \\
\text { AHP/AHA } \\
\text { Predominio masculino } \\
\text { Edad > } 50 \text { años } \\
\text { Diabetes mellitus } \\
\text { Dolor torácico/tos } \\
\text { Crepitantes/roncus } \\
\text { Dolor abdominal } \\
\text { Diarrea } \\
\text { Bilirrubina } \\
\text { FA elevada } \\
\text { Absceso único } \\
\text { Absceso del LD }\end{array}$ & $\begin{array}{c}1961 \\
\text { EE. UU. (Nueva Orleans) } \\
136 \\
58 / 51 \\
\text { Amebiano } \\
- \\
- \\
- \\
- \\
- \\
- \\
- \\
- \\
- \\
\text { Amebiano }\end{array}$ & $\begin{array}{c}1967 \\
\text { 1943-1966 } \\
\text { EE. UU. (Dallas) } \\
39 \\
24 / 15 \\
\text { Amebiano } \\
\text { Piógeno } \\
- \\
\text { Amebiano } \\
\text { Amebiano } \\
\text { NS } \\
\text { Amebiano } \\
\text { Piógeno } \\
\text { NS } \\
- \\
\text { Amebiano }\end{array}$ & $\begin{array}{c}1972 \\
\text { 1940-1969 } \\
\text { EE. UU. (Arkansas) } \\
66 \\
33 / 33 \\
\text { NS } \\
\text { Piógeno } \\
- \\
- \\
\text { NS } \\
\text { Amebiano } \\
\text { Amebiano } \\
- \\
\text { Amebiano } \\
- \\
\text { NS }\end{array}$ & $\begin{array}{c}1986 \\
\text { 1968-1983 } \\
\text { EE. UU. (California) } \\
82 \\
42 / 40 \\
\text { NS } \\
\text { Piógeno } \\
- \\
\text { NS } \\
\text { NS } \\
\text { Amebiano } \\
\text { Amebiano } \\
\text { Piógeno } \\
\text { Piógeno } \\
\text { NS } \\
\text { NS }\end{array}$ & $\begin{array}{c}1987 \\
1979-1985 \\
\text { EE. UU. (California) } \\
144 \\
48 / 96 \\
\text { Amebiano } \\
\text { Piógeno } \\
\text { Piógeno } \\
\text { Piógeno } \\
- \\
\text { Amebiano } \\
\text { Amebiano } \\
\text { Piógeno } \\
\text { NS } \\
\text { NS } \\
\text { NS }\end{array}$ & $\begin{array}{c}2004 \\
\text { 1988-1998 } \\
\text { Pakistán } \\
577 \\
106 / 471 \\
\text { Amebiano } \\
\text { Piógeno } \\
\text { Piógeno } \\
\text { NS } \\
\text { Piógeno } \\
\text { NS } \\
\text { NS } \\
\text { NS } \\
\text { NS } \\
\text { Amebiano } \\
\text { Amebiano }\end{array}$ & $\begin{array}{c}2009 \\
1985-2005 \\
\text { País Vasco (Gipúzkoa) } \\
58 \\
45 / 13 \\
\text { NS } \\
\text { Piógeno } \\
\text { Piógeno } \\
\text { NS } \\
\text { NS } \\
\text { NS } \\
\text { Amebiano } \\
\text { Piógeno } \\
\text { NS } \\
\text { NS } \\
\text { NS }\end{array}$ \\
\hline
\end{tabular}

En todos los parámetros al diferencia entre AHP y AHA fue significativa ( $p<0,5)$. Datos insuficientes para la comparación; NS: no significativa; AHP: absceso hepático piógeno; AHA: absceso hepático amebiano; FA: fosfatasa alcalina; LD: lóbulo derecho. 
bles. La técnica de PCR se considera de referencia en los inmigrantes de zonas endémicas y en viajeros habituales que tienen anticuerpos de E. histolytica durante varios años tras la infección. En la actualidad, la presencia de adhesina Gal-GalNac en el suero es una técnica muy específica para el diagnóstico de AHA, siempre que el sujeto no haya recibido tratamiento con amebicidas (27).

El tratamiento de elección en los AHP (drenaje percutáneo por ECO o TAC, asociado a antibióticos) proporciona la curación del 72 al $90 \%$ de los pacientes con una tasa de complicaciones del 4 al 18\% (28-30). Las contraindicaciones absolutas para el drenaje dirigido son la necesidad de una laparotomía por el proceso de base y los trastornos de la coagulación. Las relativas, la ascitis, el material purulento muy viscoso, los abscesos múltiples de pequeño tamaño y el riesgo de dañar una estructura vital, como sucede en aquellos localizados en el lóbulo izquierdo. La cirugía se lleva a cabo cuando fracasa el tratamiento percutáneo, existen contraindicaciones absolutas o relativas para el drenaje dirigido, enfermedades asociadas que son subsidiarias del tratamiento quirúrgico o en los abscesos que muestran ruptura o hemorragia. El tratamiento antibiótico sin drenaje es controvertido. Debe ser un recurso aplicable sólo a los enfermos con abscesos de pequeño tamaño y siempre de forma individualizada $(9,28)$. En nuestra serie, los tratamientos tan variados se explican porque los pacientes fueron vistos en épocas distintas durante los veinte años.
El tratamiento de los AHA consiste en la administración de amebicidas intraluminales y sistémicos lo antes posible. El drenaje percutáneo dirigido se lleva a cabo en los abscesos de gran tamaño (> $8 \mathrm{~cm})(31)$, en los localizados en el lóbulo izquierdo y cuando no hay respuesta al tratamiento médico o existe fallo hepático. No hay evidencia actual de que el drenaje percutáneo dirigido suponga un beneficio añadido al tratamiento con metronidazol sólo en los AHA no complicados (32). El tratamiento quirúrgico se realiza si fracasa el drenaje percutáneo o surgen complicaciones. La mortalidad es menor del $1 \%$ en los casos no complicados (sin sobreinfección ni rotura al peritoneo, pleura o pericardio).

Entre las limitaciones de este trabajo merece señalarse que es un estudio retrospectivo, observacional y que a pesar del número pequeño de casos, comparado con otros de países americanos y asiáticos, aporta una de las escasas series (12) de nuestro país en la que se analiza y compara la clínica de los enfermos con ambos tipos de abscesos hepáticos.

Como conclusión, en la presente serie los AHP ocurrieron sobre todo en personas de más de 50 años, a menudo con diabetes y por lo común se acompañaron de bilirrubina superior a $2 \mathrm{mg}$. Por otro lado, los sujetos con AHA tenían el antecedente epidemiológico de viajes o de inmigración, la diarrea fue uno de los síntomas iniciales de la enfermedad y el absceso era solitario y con preferencia por el lóbulo derecho. 